Int. J. Plant Sci. 177(6):481-497. 2016.

(c) 2016 by The University of Chicago. All rights reserved.

1058-5893/2016/17706-0002\$15.00 DOI: $10.1086 / 686794$

\title{
COMPARATIVE OVULE ONTOGENY IN SOME MEMBERS OF THE TABEBUIA ALLIANCE (BIGNONIACEAE)
}

\author{
Eduardo João Pereira Jr. ${ }^{1{ }^{*}+}+$ and Nelson Sabino Bittencourt Jr.* \\ *Departamento de Zoologia e Botânica, Instituto de Biociências, Letras e Ciências Exatas, Universidade Estadual Paulista "Júlio de Mesquita \\ Filho," Rua Cristóvão Colombo 2265, Jardim Nazareth, CEP 15054-000, São José do Rio Preto, São Paulo, Brasil; and +Programa de \\ Pós-Graduação em Ciências Biológicas (Botânica), Instituto de Biociências de Botucatu, Universidade Estadual Paulista \\ "Júlio de Mesquita Filho," Distrito de Rubião Junior s/n, CEP 18618-970, Botucatu, São Paulo, Brasil
}

Editor: Maria von Balthazar

\begin{abstract}
Premise of research. Recent phylogenetic studies placed nearly all Neotropical arboreal and shrubby species of the Bignoniaceae (excluding Jacaranda) in the Tabebuia alliance, a clade that includes all of the woody species in this family with palmately compound leaves. However, the taxa assigned to this clade have appeared in these studies as an unresolved trichotomy with Sparattosperma as its sister group. Considering the diversity and taxonomic significance of ovule morphogenesis in the extant angiosperms, this study aimed to contribute to the systematics of the Bignoniaceae by investigating ovule ontogeny in one representative of each clade of the Tabebuia alliance trichotomy: Crescentia cujete, Cybistax antisyphilitica, and Tabebuia roseoalba.
\end{abstract}

Methodology. The analysis is based on light microscopy observations of microtome semiserial sections of ovaries and ovules at several stages of development.

Pivotal results. The ovules are anatropous, unitegmic, and tenuinucellate and originate from trizonate ovule primordia. The single integument shows a concurrent epidermal and subepidermal origin, and a dark staining hypostase develops at the chalaza. Meiosis of the megaspore mother cell results in a linear or T-shaped tetrad of megaspores. The chalazal megaspore generates a monosporic Polygonum-type female gametophyte. In comparison to previous studies, our analysis of ontogenetic events demonstrates that embryological features are highly conserved in the Bignoniaceae. However, some peculiar characteristics are congruent with the systematic consideration of this study, especially the pattern of callose wall deposition during megasporogenesis and the occurrence of a protruding versus nonprotruding nucellus during early ovule development.

Conclusions. In the context of other embryological studies of the Bignoniaceae, our results support closer phylogenetic relationships among Crescentia, Handroanthus, and Tabebuia in comparison to Cybistax and indicate that the nonprotruding early nucellus is an additional character state that helps to segregate Tabebuia s.s. from other taxa in the Tabebuia alliance with a eusyncarpous ovary.

Keywords: megasporogenesis, megagametogenesis, ovule development, callose, nucellus, embryo sac.

\section{Introduction}

The Bignoniaceae is a predominantly Neotropical family that includes approximately 86 genera and 852 species (Plant List 2013). Since its proposal by De Candolle (1838), the genus Tabebuia has presented high morphological and anatomical diversity, which caused a convoluted nomenclatural history (Gentry 1969, 1992; Spangler and Olmstead 1999). Mattos (1970) split the genus into two separate groups, stressing that several Brazilian taxa known as ipês should not remain in Tabebuia. He proposed that the new genus Handroanthus should include those species with palmately compound leaves

\footnotetext{
1 Author for correspondence; e-mail: eduardojr@ibb.unesp.br.
}

Manuscript received September 2015; revised manuscript received March 2016; electronically published May 11, 2016. and eight to nine series of ovules per locule, as opposed to those species with simple leaves and ovaries with three to four series of ovules per locule in Tabebuia s.s. At first, splitting of Tabebuia (Mattos 1970) was not accepted in the international taxonomic community (Gentry 1972). However, Grose and Olmstead (2007b) redefined the boundaries of Tabebuia and related taxa, resurrecting the genera Handroanthus Mattos and Roseodendron Miranda as separate clades from Tabebuia.

Grose and Olmstead (2007a) recognized a clade in the Bignoniaceae that was comprised of all species that were previously assigned to Sparattosperma, Cybistax, Zeyheria, Godmania, Tabebuia, Ekmanianthe, Spirotecoma, and the Crescantieae (Parmentiera, Crescentia, and Amphitecna) and named that clade the Tabebuia alliance. The other genera that are currently placed within this alliance are Paratecoma and possibly Romeroa (Olmstead et al. 2009). The morphological character that unites the members of this group and distinguishes them from 
other Bignoniaceae is digitate compound leaves, although a reduction to the unifoliate condition occurred independently in some taxa. This clade is a sister group of the Paleotropical clade sensu Olmstead et al. (2009) that consists of an assemblage of Old World genera with a corresponding paraphyletic relationship to the Coleeae, a clade endemic to Madagascar. The Tabebuia alliance has some problems concerning the phylogenetic positioning of its inner groups (Grose and Olmstead 2007a, 2007b; Olmstead et al. 2009). In a molecular cladistic study performed by Olmstead et al. (2009) using the $n d h F, t r n L-F$, and $r b c L$ plastid DNA sequences, the small tropical South American genus Sparattosperma appeared as the sister group of an unresolved trichotomy, with one of the clades including Handroanthus, Roseodendron, Crescentieae, and Spirotecoma; a second clade consisting of Tabebuia and its Caribbean sister group Ekmanianthe; and a third clade including Cybistax, Godmania, and Zeyheria.

In plant systematics, reproductive characteristics constitute most of the characters that have taxonomic importance (Anderson et al. 2002). In its broadest sense, embryological information is complementary to molecular phylogenetics, and it is particularly valuable in delimiting genera because embryological characters show very little plasticity in comparison to many vegetative characters (Tobe 1989; Berg 2009). However, while the amount of molecular data used in phylogenetic studies is increasing, detailed morphological/ontogenetic features are largely missing, or the existing data must be re-evaluated (Erbar and Gülden 2011), which makes it difficult to map such features in phylogenetic reconstructions and use them in taxonomic studies of flowering plants. Because of the hardly accessible nature of the embryological data, which normally requires the use of time-consuming microtechniques, and the need for a large number of characters in a representative group of taxa to validate a specific hypothesis, the use of embryological information in phylogenetic analysis is a challenge. Despite these obstacles, efforts should be made to use embryological characters in phylogenetic studies more frequently and more regularly because these characters represent an additional source of useful data when other types of evidence are not yet fully available or have failed to solve systematic problems (Tobe 1989).

In this study, we investigate ovule development in Crescentia cujete, Cybistax antisyphilitica, and Tabebuia roseoalba-including megasporogenesis and megagametogenesis - to improve our understanding of the development and organization of female gametophytes in the Bignoniaceae, to identify relevant embryological data that could be used in the reconstruction of the phylogeny of the family, and to elucidate the interrelationships among the three major groups of the Tabebuia alliance.

\section{Material and Methods}

This study was performed from 2008 to 2013. Tabebuia roseoalba (Ridl.) Sandwith occurs in Eastern and Central Brazil and adjacent Paraguay, with a disjunct population in Peru (Gentry 1992). This species is a $4-25-\mathrm{m}$-tall ornamental tree, which is highly appreciated for its white or pale pink corollas and massive flowering and is broadly used for urban afforestation in Brazil. Cybistax antisyphilitica (Mart.) Mart. is a 1.5-20-m-tall tree that is commonly found in the Brazilian savannah-like Cerrado vegetation but has a wider natural distribution. This tree occurs in all of the extra-Amazonian territory of Brazil (except for the far northeast), Paraguay, Bolivia, and the driest areas of the Amazonian slope of the Peruvian Andes, with a disjunct population at the extreme south of Suriname (Gentry 1992). Crescentia cujete $\mathrm{L}$. is a small tree that is up to $10 \mathrm{~m}$ tall and apparently originated from Central America and Mexico but is now widely distributed in the tropics (Gentry 1980; Arango-Ulloa et al. 2009). This tree is also cultivated as ornamental because of its peculiar, large, spherical to ovoid-elliptic calabash fruit. Voucher specimens were deposited in the São José do Rio Preto herbarium: Cy. antisyphilitica $(26448,29238)$, T. roseoalba $(29239,29240$, 29241), C. cuiete (31876, 31877).

Flowers and flower buds in several stages of development were collected from three to five individuals of each species that were located on the campus of the São Paulo State University (Universidade Estadual Paulista "Júlio de Mesquita Filho"), which is in the municipality of São José do Rio Preto, Brazil. After dissection, the ovaries were fixed in $4 \%$ paraformaldehyde and $1 \%$ glutaraldehyde in $0.1 \mathrm{M}$ sodium phosphate buffer at pH 7.2 (McDowell and Trump 1976) and stored in 70\% ethanol. For nuclear visualization, part of the ovaries were fixed for $24 \mathrm{~h}$ in a $3: 1$ solution of $95 \%$ ethanol:acetic acid and stored in $70 \%$ ethanol before $4 '$,6-diamidino-2-phenylindole (DAPI) staining procedures (Williams and Friedman 2002). After complete dehydration in an ethanol series, the samples were embedded in Leica historesin (glycol methacrylate) and sectioned with glass knives using a Leica RM 2255 rotary microtome (Leica, Wetzlar). The 1-4- $\mu$ m-thick sections were semiserial. They were mounted on glass slides and subjected to histochemical tests or stained with toluidine blue O (O'Brien and McCully 1981) and sealed with Permount.

The following histochemical tests were used: the periodic acid-Schiff (PAS) reaction for the detection of insoluble polysaccharides, after treating the sections with aldehyde blocker (O'Brien and McCully 1981); aniline blue as a fluorochromatic method to detect callose (Eschrich and Currier 1964); and ruthenium red to detect acid polysaccharides, including pectic acids (Southworth 1973). To visualize the nuclei of the mature female gametophyte, the sections of the ovaries that were fixed in the ethanol:acetic acid solution were immersed in $0.25 \mu \mathrm{g} / \mathrm{mL}$ of DAPI in a $0.05 \mathrm{M}$ Tris buffer $(\mathrm{pH} 7.2)$ at room temperature and in a light-free environment for $15 \mathrm{~min}$ (Williams and Friedman 2002). All bright field analyses were performed using a Zeiss Axioskop microscope (Carl Zeiss, Jena). DAPI- and aniline blue-stained sections were visualized using an Olympus BX51 light microscope (Olympus Optical, Tokyo) equipped with a reflected fluorescence system (mercury burner USH-103OL, cube model U-MWU2, excitation filter BP330-385, dichronic mirror DM400, and barrier filter BA420). Photographic records were made with the same Olympus microscope system using an Olympus Q-Color 5 digital camera.

\section{Results}

\section{Megasporogenesis and Integument Development}

Crescentia cujete has a bicarpellate paracarpous ovary with four placental ridges (two per carpel) on the internal surface of the ovary wall that delimit the major part of a single locule 
(figs. 1C, 2A). In contrast, Tabebuia roseoalba and Cybistax antisyphilitica have a bicarpellate eusyncarpous ovary, with two placental ridges on each face of the septum (figs. $1 A, 1 B$, $4 B, 6 A)$. The ovules are arranged on the surfaces of the placental ridges. The number of ovules per placental ridge in a median transverse section of the ovary is typically just one in $T$. roseoalba, four to six in Cy. antisyphilitica, and more than 16 in C. cujete. While the ovule position in both T. roseoalba and Cy. antisyphilitica is pleurotropous-ventral (i.e., with the micropyle pointing to the side and away from the center of the carpel; fig. $1 A, 1 B$ ), in C. cujete, the ovules are heterotropous (i.e., the ovule position varies in orientation).

In the three species, before the initiation of ovule ontogeny, cell division patterns at the peripheral layers of the placental meristems generate a trizonate organization (sensu Bouman 1984; figs. $2 B, 4 A, 6 B$ ). In the epidermal layer (zone 1), cell divisions are only anticlinally oriented. In the subepidermal layer (zone 2), anticlinal divisions predominate, although some oblique and periclinal divisions were also observed (figs. $2 B$, $4 A, 6 B)$. There was no regular pattern for the cell divisions in the third and subjacent layers (zone 3 ) of the placentae (figs. 2B, 4A, 6B), and ovule protrusion initiates via cellular proliferation in this last zone. The emerging ovule primordia are also trizonate and show the same patterns of zone 1-3 cell divisions that were observed in the prospective placentae (figs. $2 D, 4 C, 6 D$ ). In each carpel of an ovary cross section, C. cujete shows a diffuse distribution of many ovule primordia on the placental surface (fig. 2C), whereas Cy. antisyphilitica has eight to 12 (fig. $6 \mathrm{C}$ ), and $T$. roseoalba has only two ovule primordia per carpel (fig. 4B).

After the emergence of the ovule primordia from the placental surface, a single archesporial cell typically differentiates

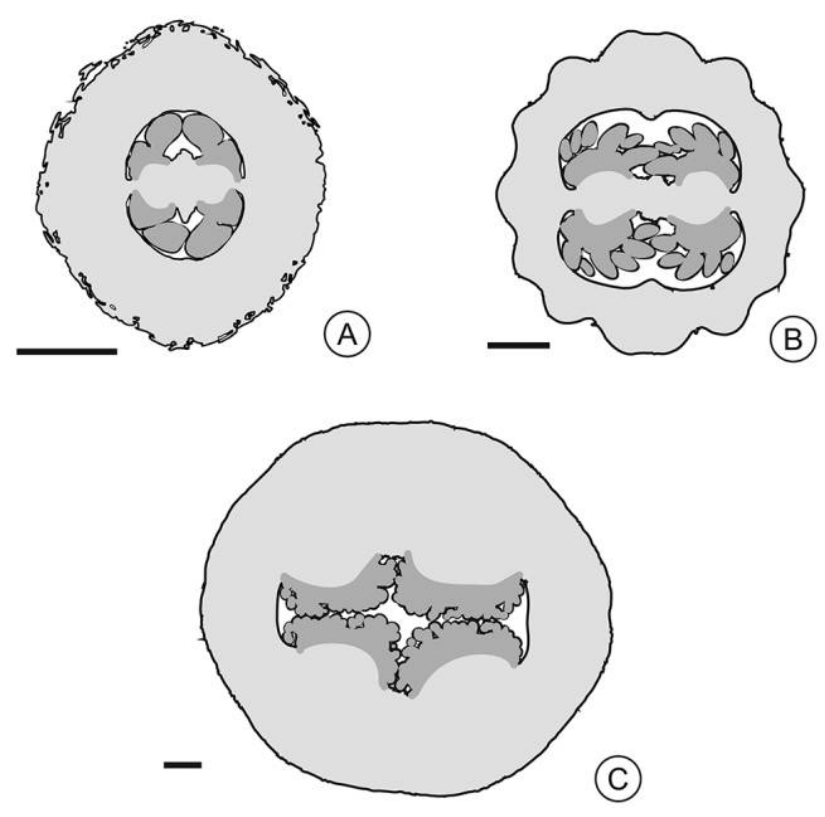

Fig. 1 Median transverse sections of ovaries at the anthesis stage in Tabebuia roseoalba $(A)$ and Cybistax antisyphilitica $(B)$, both at the synascidiate region, and in Crescentia cujete $(C)$. Ovule rows and placental ridges are in dark gray. in the subepidermal layer at a top-lateral position in the nucellus. This cell exhibits a dense cytoplasm and a prominent nucleus. Although the archesporium expansion results in the protrusion of the covering nucellar epidermis in C. cujete (fig. $2 E$, $2 F$ ) and Cy. antisyphilitica (fig. $6 E, 6 F$ ), this pattern was not observed in the first stages of archesporium differentiation in $T$. roseoalba (fig. 4C, 4D). This difference may be related to space limitation in each locule. In all species, archesporial cells develop several small vacuoles in the cytoplasm (figs. $2 F, 4 E, 6 F, 6 G$ ).

Cell proliferation and expansion in one side of the young ovule cause an anatropous curvature (figs. $2 \mathrm{G}, 4 \mathrm{~F}, 6 \mathrm{H}$ ). In this stage, a group of cells on the raphal side that belong to zone 3 start to elongate in longitudinal direction of the ovule and show an increasing cytoplasmic density, differentiating into the provascular bundle of the funiculus (figs. $2 H, 4 E, 6 G, 6 H$ ).

The single archesporial cell does not divide, and as archesporium differentiation proceeds, a single integument arises by periclinal divisions from a set of protodermal cells (zone 1) around the base of the archesporium (figs. $2 E, 4 D, 6 E, 6 F$ ). Subsequently, the subjacent cells (zone 2) also divide periclinally, pushing the cells of epidermal origin to the distal portion of the nucellus, where the micropyle will be formed. This process causes a loss of boundaries between epidermal and subepidermal cells in the developing integument (figs. $2 F, 2 G, 4 E, 4 F$, $6 \mathrm{G}, 6 \mathrm{H})$. Zone 3 cells of the young ovule do not participate in the integument formation. The cells of the outer layer of the integument divide anticlinally, whereas oblique and periclinal divisions occur in the inner cell layers, which contribute to the thickening of the integument around the nucellus (figs. 2G-2I, $4 F, 6 H-6 J)$.

The archesporium increases considerably in volume while undergoing premeiotic cellular differentiation (PCD) without giving rise to any parietal cells. Therefore, the archesporial cell differentiates directly into a megaspore mother cell (MMC). Even when more than one archesporial cell (identified by their larger volume, cytoplasmic density, and nuclear size relative to the neighboring somatic cells) is initially present in an ovule, only one of those cells (usually the larger one) undergoes PCD to form an MMC. In all of the studied species, PCD was characterized not only by cell elongation but also by lateral expansion, especially at the distal (micropylar) end, which gives the MMC an oval or club shape (figs. $2 G-2 I, 4 F-4 H, 6 H, 6 I$ ). During the PCD phase, the centrally positioned nucleus continues to enlarge, becoming up to three to four times larger in a mature MMC than in any neighboring integumentary cell. In addition, the nucleus has a prominent nucleolus (figs. $2 \mathrm{G}-2 \mathrm{I}, 4 \mathrm{~F}-4 \mathrm{H}, 6 \mathrm{H}$, 6I). The early MMC in C. cujete has two large vacuoles, one at the chalazal pole and the other at the micropylar pole of the cell (fig. 2G), while in T. roseoalba and Cy. antisyphilitica, the early MMC shows a bipolar vacuome that consists of numerous small, rounded vacuoles (fig. $4 H$ ). However, these vacuoles are lost during prophase I of meiosis (figs. 2I, 6J), except for T. roseoalba, whose meiocyte vacuolization persists until the dyad stage (fig. $4 H$ ).

Most of the MMC surface is covered by a nucellar epidermis, except for the proximal portion that is in close contact with the chalaza (figs. $2 G-2 I, 4 F-4 H, 6 G-6 J$ ). In T. roseoalba, amyloplast formation in all cells of the ovule primordium initiates simultaneously with the appearance of the archesporium (fig. 4D). In C. cujete and Cy. antisyphilitica, small amyloplasts 

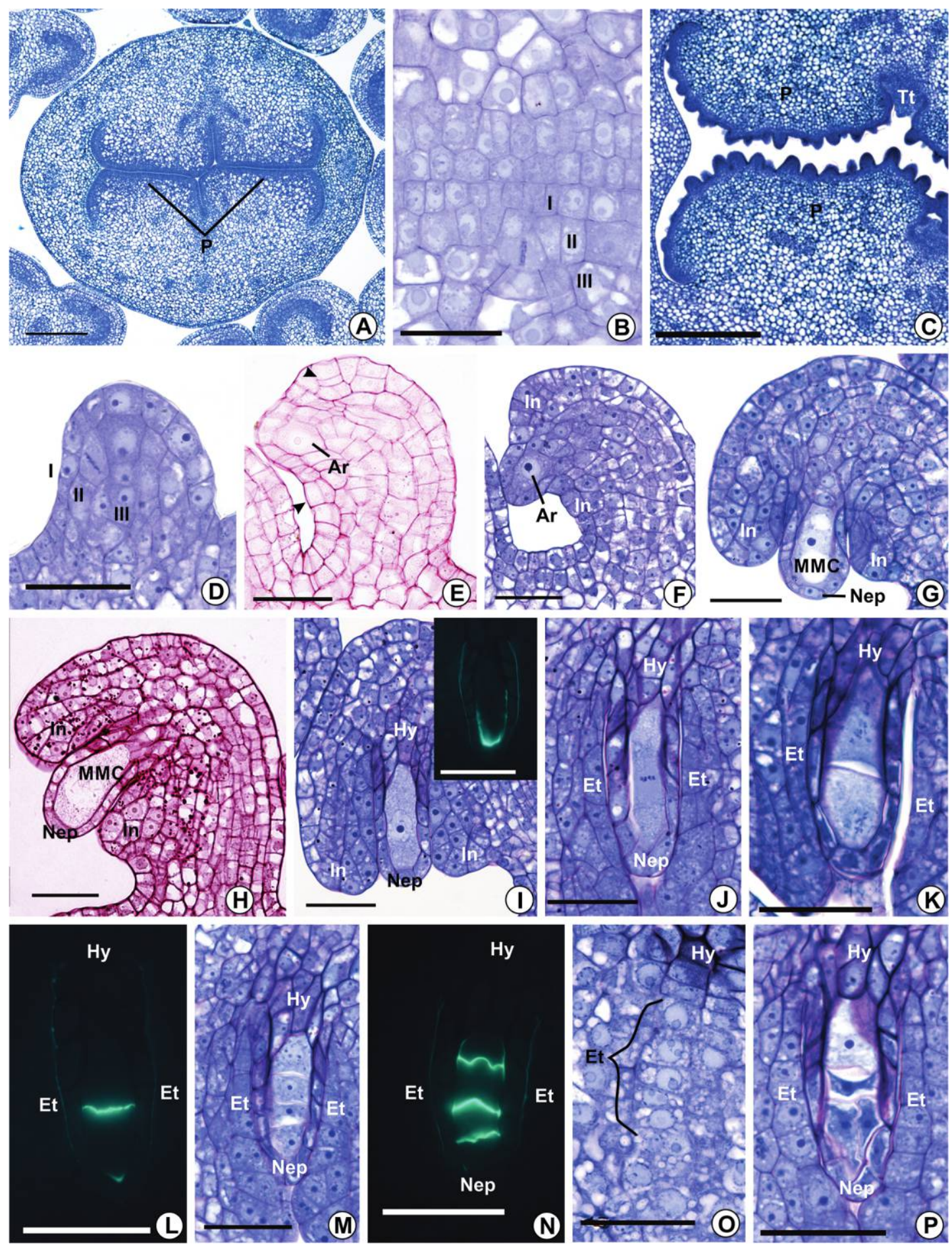

Fig. 2 Megasporogenesis in Crescentia cujete. A-C, Transverse section of the paracarpous ovary. A, General aspect before locule expansion and ovule initiation. $B$, Contiguous placental meristems from opposite carpels showing a trizonate structure before the emergence of the locular cavity and young ovules. $C$, After initial expansion of the locular cavity, with ovule primordia on the placental surfaces. $D-P$, Longitudinal sections of developing ovules. $D$, Trizonate ovular primordium before archesporium emergence. $E$, $F$, Protruding nucellus. Arrowheads indicate periclinal divisions at the epidermal layer. $G$, Polarized cytoplast of megaspore mother cell (MMC) with a spherical vacuole at each pole. $H$, Amyloplast distribution in an ovule at the premeiotic MMC stage. I, Prophase I of the MMC. Insert shows callose wall deposition. J, Metaphase I of the MMC. K, Dyad. $L$, Callose deposition on the transverse wall of the dyad and in distal walls of the micropylar cell. $M$, Tetrad of megaspores. $N$, Callose on the transversal wall and part of the lateral walls of the tetrad. $O$, Tangential section of the ovule showing tangentially elongate endothelial cells. $P$, T-

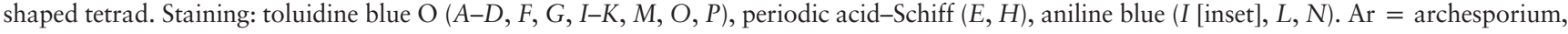
$\mathrm{Et}=$ endothelium, $\mathrm{Hy}=$ hypostase, In = integument, I = epidermal layer (zone 1), II = subepidermal layer (zone 2), III = corpus (zone 3), Nep = nucellar epidermis, $\mathrm{P}=$ placenta, $\mathrm{Tt}=$ transmitting tissue. Scale bars $=200 \mu \mathrm{m}(A), 30 \mu \mathrm{m}(B, D-P), 50 \mu \mathrm{m}(C)$. 

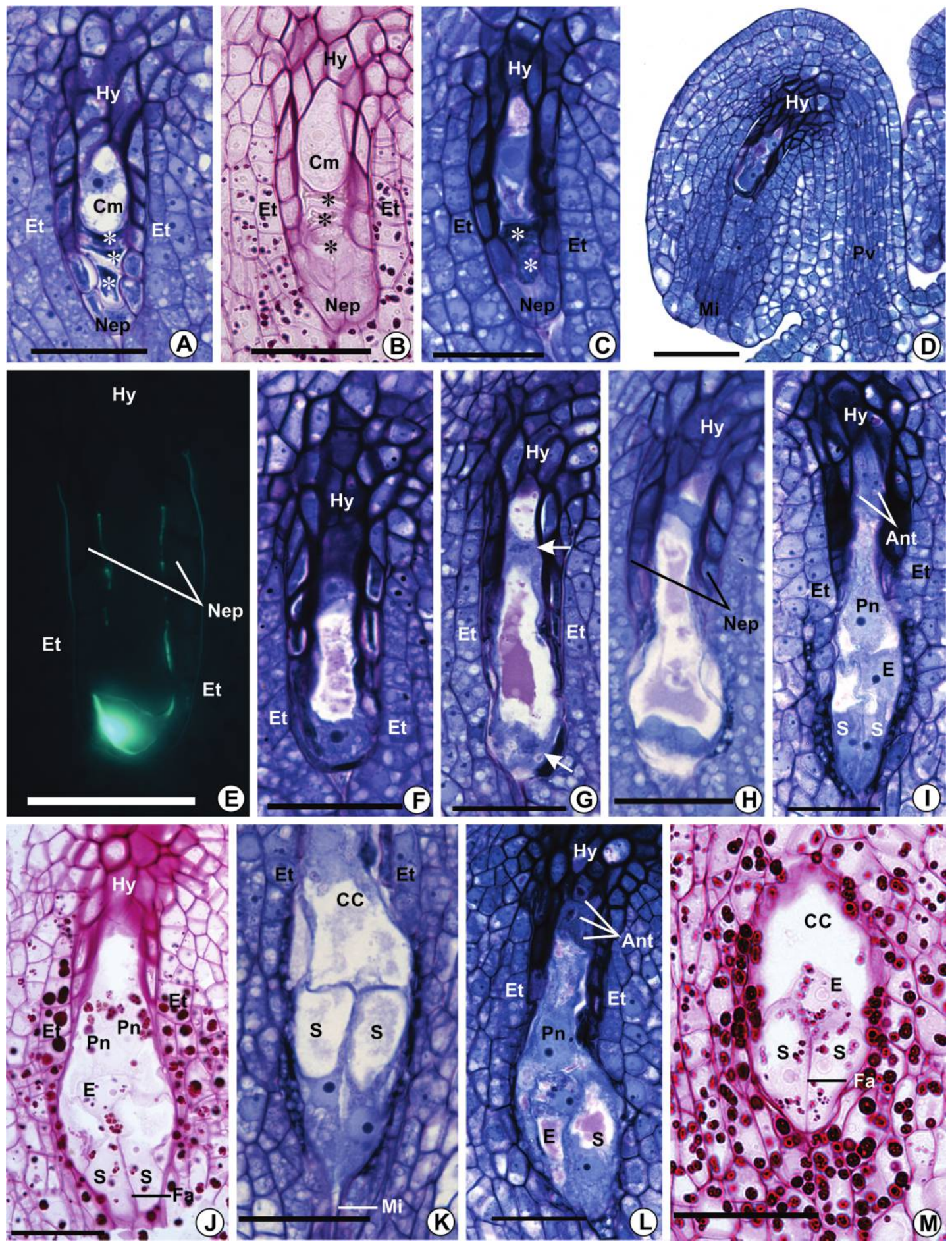

Fig. 3 Megagametogenesis in Crescentia cujete. Longitudinal sections of developing ovules. A, $B$, Late linear tetrad of megaspores. $C$, Uninucleate megagametophyte. $D$, General view of ovule section at the binucleate stage of the megagametophyte. $E$, Callose cap at the micropylar end of a binucleate megaspore. F, Megagametophyte at a late binucleate stage. $G$, Second cycle of karyokinesis in the megagametophyte. Arrows indicate metaphase plates. $H$, Megagametophyte at the tetranucleate stage. $I-M$, Mature megagametophyte. $I, J, L$, General aspect. $K, M$, Egg apparatus. Ant $=$ antipodals, $\mathrm{CC}=$ central cell, $\mathrm{Cm}=$ chalazal megaspore/uninucleate megagametophyte, $\mathrm{E}=$ egg cell, $\mathrm{Et}=\mathrm{endothelium}$, $\mathrm{Fa}=$ filiform apparatus, $\mathrm{Hy}=$ hypostase, $\mathrm{Mi}=$ micropyle, $\mathrm{Nep}=$ nucellar epidermis, $\mathrm{Pn}=$ polar nucleus, $\mathrm{S}=$ synergids, $\mathrm{Pv}=$ provascular bundle. Staining: toluidine blue $\mathrm{O}(A, C, D, F-I, K, L)$, periodic acid-Schiff $(B, J, M)$, aniline blue $(E)$. Scale bars $=30 \mu \mathrm{m}(A-C, E-M), 50 \mu \mathrm{m}$ $(D)$. 

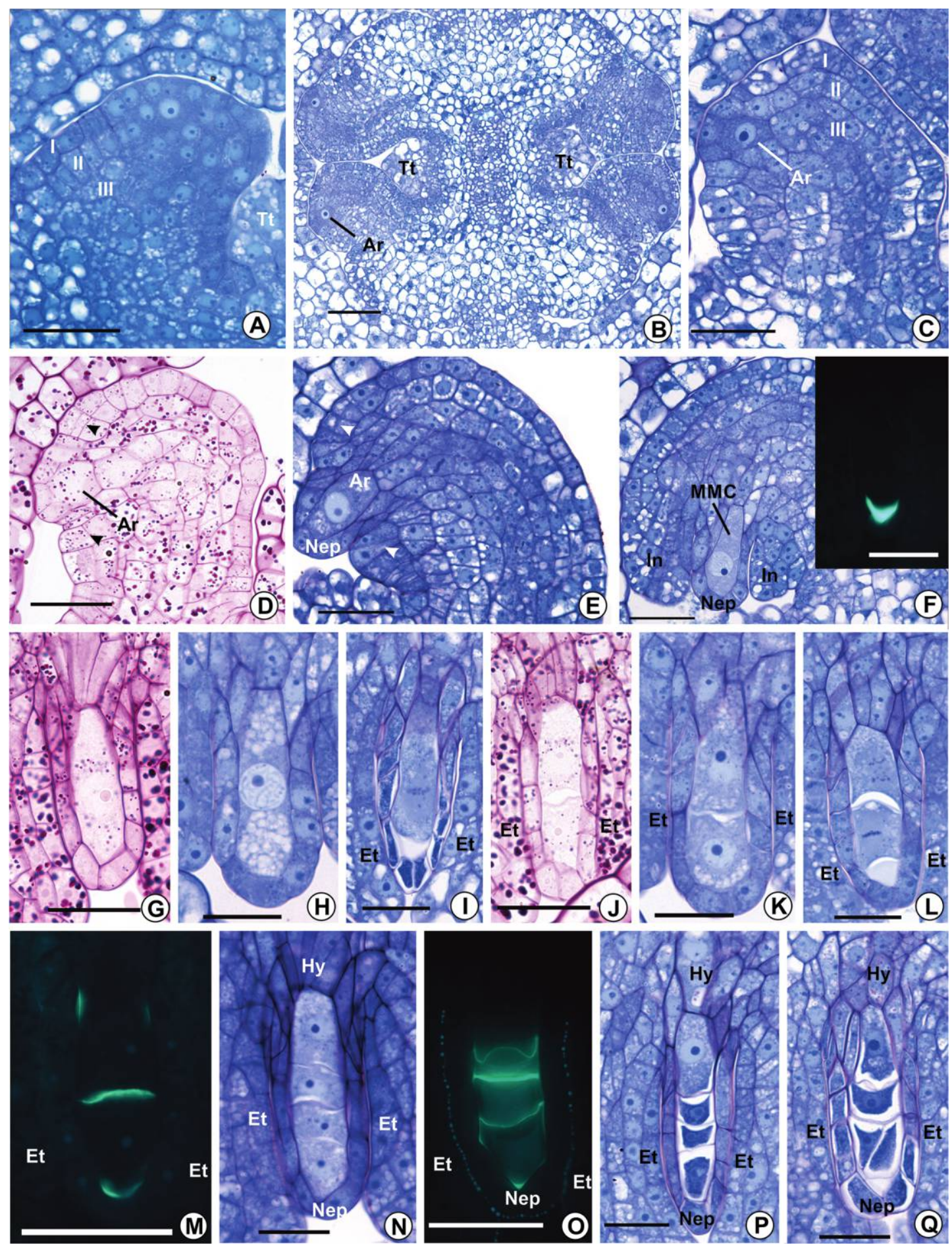

Fig. 4 Megasporogenesis in Tabebuia roseoalba. A, Placenta with trizonate structure before the emergence of ovule primordia. $B$, Ovary transversal section showing two ovule primordia per carpel. The ovules are at the differentiating archesporium stage. $C-Q$, Longitudinal sections of developing ovules. C, Trizonate young ovule with recently differentiated archesporial cell. $D$, Young ovule with epidermal layer showing periclinal divisions (arrowheads) around the base of the archesporium. E, Differentiation of the megaspore mother cell (MMC). F- $H$, MMC at successive points of the prophase I stage. Inset in $F$ shows callose wall deposition. A bipolar vacuome is seen in H. I, MMC at the metaphase I stage. J-M, Dyad stage. A polarized vacuome is seen in each cell in $K$. $L$, Chalazal and micropylar cells in anaphase II and metaphase II, respectively. $M$, Callose wall distribution. N, Early linear tetrad of recently formed megaspores. $O-Q$, Late tetrad stages. $O$, Callose in transversal and lateral walls of the megaspores. $P$, Linear tetrad. $O$, T-shaped tetrad. $\mathrm{Ar}=$ archesporium, $\mathrm{Et}=$ endothelium, $\mathrm{Hy}=$ hypostase, $\mathrm{In}=$ integument, $\mathrm{I}=$ epidermal layer (zone 1), II = subepidermal layer (zone 2), III = corpus (zone 3), $\mathrm{Nep}=$ nucellar epidermis, $\mathrm{Tt}=$ transmitting tissue. Staining: toluidine blue $\mathrm{O}(A-$ $C, E, F, H, I, K, L, N, P, Q)$, periodic acid-Schiff $(D, G, J)$, aniline blue $(F$ [inset], $L, N)$. Scale bars $=30 \mu \mathrm{m}(A, C-P), 50 \mu \mathrm{m}(B)$. 

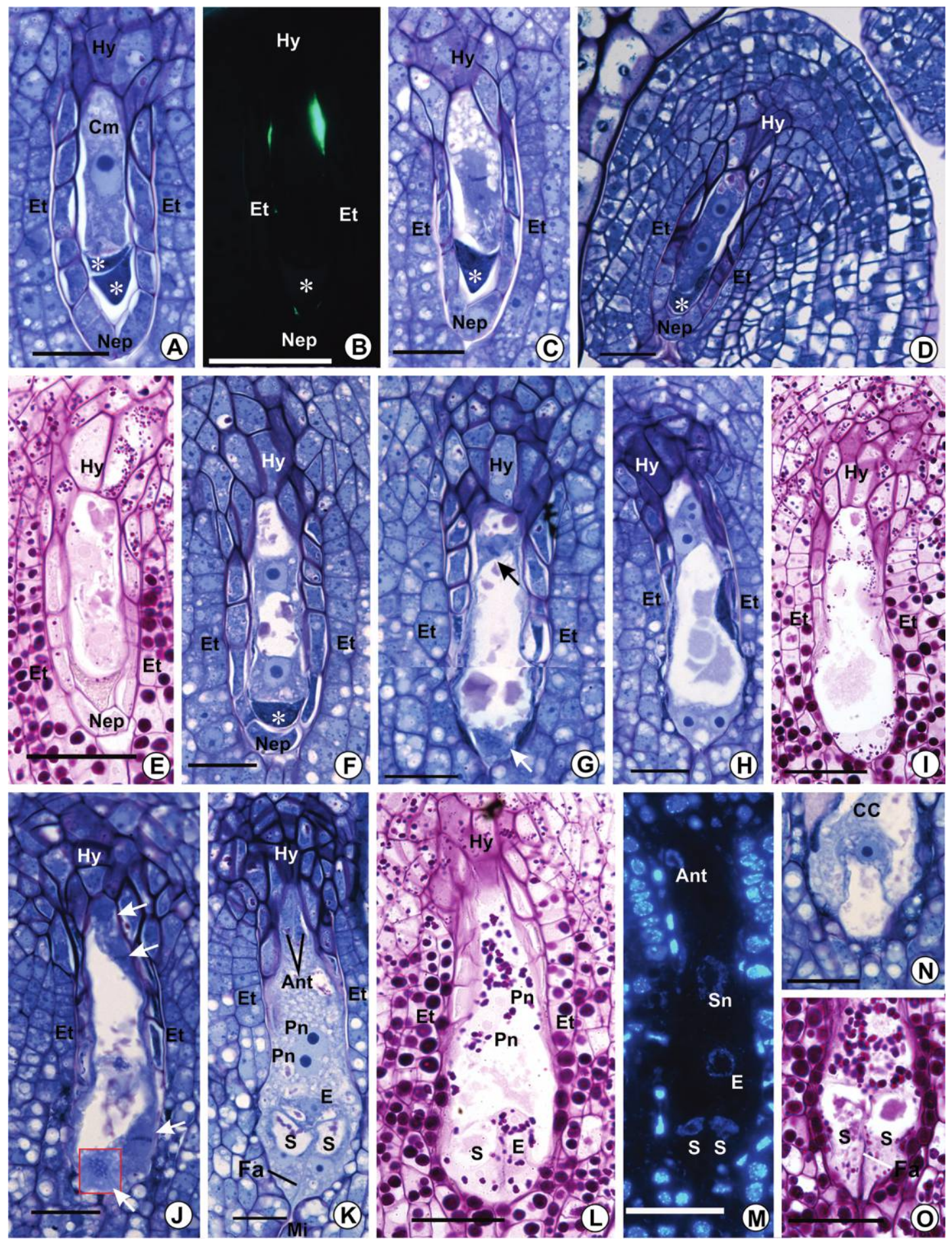

Fig. 5 Megagametogenesis in Tabebuia roseoalba. Longitudinal sections of developing ovules. $A, B$, Uninucleate megagametophyte. $A$, Collapsed nonfunctional megaspores (asterisks). B, Callose deposition at the lateral walls. C, First acytokinetic mitosis. $D-F$, Binucleate megagametophyte in successive stages. $G$, Second cycle of karyokinesis in the megagametophyte. Arrows point to metaphase plates. $H, I$, Tetranucleate stage. $J$, Last mitotic cycle in the megagametophyte. Arrows indicate metaphase plates. $K-O$, Mature megagametophytes. $L$, Amyloplast distribution in the megagametophyte and surrounding tissues. $M$, Nuclei of the cells that compose the megagametophyte. $N, O$, Egg apparatus. $N$, Egg cell. $\mathrm{O}$, Synergids. Ant $=$ antipodals, $\mathrm{CC}=$ central cell, $\mathrm{Cm}=$ chalazal megaspore/uninucleate megagametophyte, $\mathrm{E}=\mathrm{egg}$ cell, $\mathrm{Fa}=$ filiform apparatus, $\mathrm{Et}=$ endothelium, $\mathrm{Hy}=$ hypostase, $\mathrm{Mi}=$ micropyle, $\mathrm{Nep}=$ nucellar epidermis, $\mathrm{Pn}=$ polar nucleus, $\mathrm{S}=$ synergids, $\mathrm{Sn}=$ secondary nucleus. Staining: toluidine blue $\mathrm{O}(A, C, D, F-H, J, K, N)$, aniline blue $(B)$, periodic acid-Schiff $(E, I, L, O)$, 4',6-diamidino-2-phenylindole (M). Scale bars $=30 \mu \mathrm{m}$. 

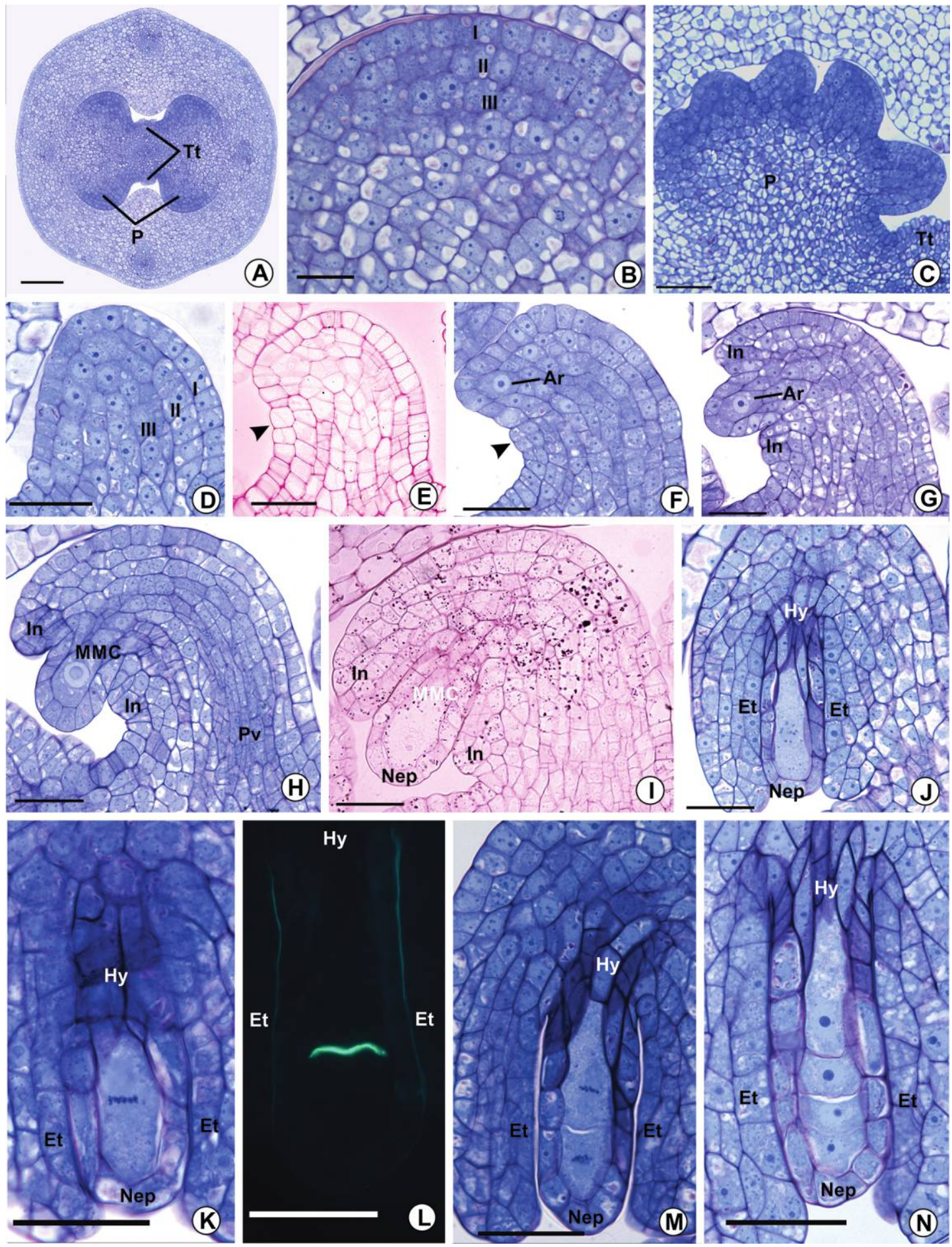

Fig. 6 Megasporogenesis in Cybistax antisyphilitica. $A-C$, Transverse sections of the ovary. A, General aspect. $B$, Placenta with trizonate meristem organization before the emergence of the young ovules. C, Placenta with emerging young ovules. $D-N$, Longitudinal sections of developing ovules. D, Trizonate organization of the young ovule. E, F, Young ovules showing nucellus protrusion and the archesporial cell. Arrowheads indicate periclinal divisions of epidermal cells next to the base of the archesporium. G, Young ovule in a more advanced stage with the emerging integument. $H-I$, Differentiation of the megaspore mother cell (MMC). $J$, Ovule at the prophase I stage of the MMC. $K$, Metaphase I of the MMC. L, Callose deposition in the transversal walls of the dyad. M, Dyad with both cells in metaphase II. N, Tetrad of megaspores with elongated chalazal megaspore. $\mathrm{Ar}=$ archesporium, $\mathrm{Et}=$ endothelium, $\mathrm{Hy}=$ hypostase, $\mathrm{In}=$ integument, $\mathrm{I}=$ epidermal layer $(\mathrm{zone} 1)$, II = subepidermal layer (zone 2), III = corpus (zone 3), $\mathrm{Nep}=$ nucellar epidermis, $\mathrm{P}=$ placenta, $\mathrm{Tt}=$ transmitting tissue, $\mathrm{Pv}=$ provascular bundle. Staining: toluidine blue $\mathrm{O}(A-D, F-H, J, K, M, N)$, periodic acid-Schiff $(E, I)$, aniline blue $(L)$. Scale bars $=100 \mu \mathrm{m}(A), 20 \mu \mathrm{m}(B), 50 \mu \mathrm{m}(C)$, $30 \mu \mathrm{m}(D-N)$ 
start to appear in the chalaza, nucellar epidermis, and integument only at the end of the PCD phase of the MMC, when the integument border reaches halfway to the top of the nucellus (figs. 2H, 6I). In Cy. antisyphilitica and T. roseoalba, amyloplasts were observed in the cytoplasm of the MMC, dyads, and the chalazal megaspore (figs. 4G, 4J, 6I). However, PAS staining in ovule sections from C. cujete did not reveal starch grains in $\mathrm{MMC}$, dyads, and tetrads, and nonsomatic cell amyloplasts in this species appeared from only the bicellular stage of the developing megagametophyte onward (not shown).

By the stage in which meiotic prophase I occurs in the MMC, the single integument border reaches the top of the nucellar epidermis (figs. $2 I, 4 G, 6 J$ ). At this stage, the 1-3 inner cell layers of the integument (i.e., those layers next to the nucellar epidermis) begin to form a poorly differentiated endothelium. In these cells, the centrally positioned nucleus may occupy more than half of the protoplasmic volume, with a prominent nucleolus (figs. 2I, 2P, 6J). These cells also show a higher cytoplasm density than those of the outer cell layers of the integument (figs. 2J$2 P, 4 I-4 Q, 6 J-6 N)$ and are tangentially elongated (fig. 2O). From the meiotic prophase stage on (fig. $4 G$ ), the inner layers of the integument (including the endothelium) begin to show an increasing gradient of number and size of amyloplasts toward the nucellar epidermis (figs. 3B, 3J, 3M, 5E, 5I, 5L, 7C, 7I, 7P).

Even during the differentiation of the MMC, the cells of the chalaza that are located between the chalazal end of the MMC and the distal end of the provascular bundle and the cells of the nucellar epidermis next to this region begin to differentiate into a hypostase. These cells generate a stronger cytoplasmic density than the neighboring somatic cells, and their walls, including those facing the MMC, not only thicken but also start to show an intense reddish purple staining with toluidine blue $\mathrm{O}$ (figs. $2 \mathrm{I}-2 \mathrm{~K}, 2 \mathrm{M}, 2 \mathrm{O}-2 \mathrm{P}, 4 \mathrm{H}, 4 \mathrm{I}, 4 \mathrm{~K}, 4 \mathrm{~L}, 4 \mathrm{~N}, 4 \mathrm{P}, 4 \mathrm{Q}, 6 \mathrm{~J}$, $6 \mathrm{~K}, 6 \mathrm{M}, 6 \mathrm{~N}$ ). These cell walls are also PAS positive (figs. $2 \mathrm{H}$, $3 B, 4 G, 4 J$ ), and ruthenium red staining (data not shown) indicates that they are rich in pectic substances. These nucellar cells have vacuoles with a dense granular content that stains reddish purple with toluidine blue $\mathrm{O}$ (figs. $2 J, 4 Q, 6 M$ ) and is PAS positive (figs. 5E, 5I, 7C, 7I). The same vacuolar content occurs in most other cells of the ovule at different stages but with a lower staining intensity. Because of its position, the hypostase clearly connects the MMC-and the developing megagametophyte in later stages (see below) - with the provascular bundle (fig. $3 D$ ). Sometimes T. roseoalba shows binucleate cells in the hypostase, which are usually aligned with the longitudinal axis of the archesporium/MMC/megaspores/ megagametophyte and often show a bipolar vacuome (figs. $4 E$, $4 H, 4 L, 4 P, 5 E)$.

During meiotic divisions of the MMC, the metaphase plates are perpendicularly oriented to the meiocyte longitudinal axis (figs. 2J, 4I, 4L, 6K, 6M), and after successive cytokinesis, a linear tetrad of megaspores is generated (figs. $2 J-2 \mathrm{~N}, 4 I-4 P, 6 \mathrm{~K}-$ $6 \mathrm{~N}, 7 A)$. However, C. cujete and T. roseoalba also exhibited a percentage of T-shaped tetrads: $3.3 \%$ and $11.3 \%$ in 61 and 71 examined tetrad stage ovules, respectively (figs. $2 P, 4 Q$ ). Often, no synchrony is observed between the two cells of a dyad after the first meiotic cytokinesis because the events of the second division (e.g., anaphase II chromosome migration) occur faster in the chalazal cell (fig. $4 L$ ). In the tetrad stage, the integument border typically covers the top of the nucellus, initiating micropyle organization in C. cujete and T. roseoalba (figs. $2 M, 4 P$, $4 Q$ ). In Cy. antisyphilitica, the micropyle begins to be organized primarily after the initial expansion of the chalazal megaspore to form the uninucleate megagametophyte (fig. 7C, 7D). However, in all of the plants under study, the point at which the micropyle started to be organized varied from the early tetrad stage to chalazal megaspore expansion.

In the three species, patterns of callose deposition were observed in the walls of the MMC, dyads, tetrads, and early cenocytic phases of the embryo sac (fig. 8). In C. cujete and T. roseoalba, callose deposition initiates in the lateral and distal walls of the micropylar portion of MMCs during prophase I or metaphase I (figs. $2 I$ [inset], $4 F$ [inset]), but Cy. antisyphilitica did not show any evidence of callose deposition during these stages. In all species, cytokinesis was followed by callose deposition on both sides of the pectocellulosic transverse wall at the dyad stage (figs. $2 L, 4 M, 6 L$ ). In C. cujete and T. roseoalba, callose persists in the distal wall of the micropylar cell in the dyad stage (figs. $2 L, 4 M$ ). In T. roseoalba, callose deposition also occurs in the proximal portion of the lateral walls in the chalazal cell of the dyad (fig. 4M), and numerous spherical vacuoles concentrate next to the proximal wall of this cell and the distal wall of the micropylar cell (fig. $4 K$ ). In the three species, the deposition of callose occurs again on both sides of the transverse wall of megaspores after linear tetrad formation (figs. $2 \mathrm{~N}, 4 \mathrm{O}, 7 \mathrm{~B}$ ). In the tetrad stage, callose deposition also occurs to some extent at the lateral walls of the megaspores in C. cujete (fig. $2 \mathrm{~N}$ ), and callose is deposited on all walls except for the lateral and basal walls in the chalazal portion of the chalazal megaspore in T. roseoalba (fig. 4O). We did not find callose deposition in the lateral walls of the megaspores in Cy. antisyphilitica (fig. $7 B$ ). In C. cujete, callose persists along the lateral walls of the uninucleate and early binucleate megagametophyte (fig. $3 E$ ), and callose remnants persist in the proximal portion of the lateral walls of the uni- to binucleate megagametophyte in T. roseoalba (fig. 5B). In C. cujete and Cy. antisyphilitica, a thick callose hoodwhich is derived from the fusion of the transverse walls of the collapsed nonfunctional megaspores-persists until the binucleate stage of the early megagametophyte (figs. $3 E, 7 H$ ) and becomes progressively thinner until disappearing in the subsequent stages of development. The same callose hood is formed after the collapse of the micropylar megaspores in T. roseoalba but quickly disappears (fig. 5B).

After megasporogenesis is complete, the chalazal megaspore elongates parallel to the longitudinal tetrad axis, showing a conspicuous central nucleus (figs. $2 P, 3 A, 3 B, 4 P, 4 Q$, $6 N, 7 A, 7 C)$. This event marks the differentiation of the functional megaspore into the single-nucleated phase of the megagametophyte. Cells around the micropylar canal show a large number of conspicuous amyloplasts, which persist until ovule maturity, immediately before anthesis (figs. $3 \mathrm{M}, 5 \mathrm{E}, 5 \mathrm{I}, 5 \mathrm{~L}$, $50)$.

\section{Megagametogenesis}

The functional megaspore/single-nucleate embryo sac has a polarized cytoplasm with vacuoles that contain granular content in C. cujete, T. roseoalba, and Cy. antisyphilitica (figs. $3 A$, 

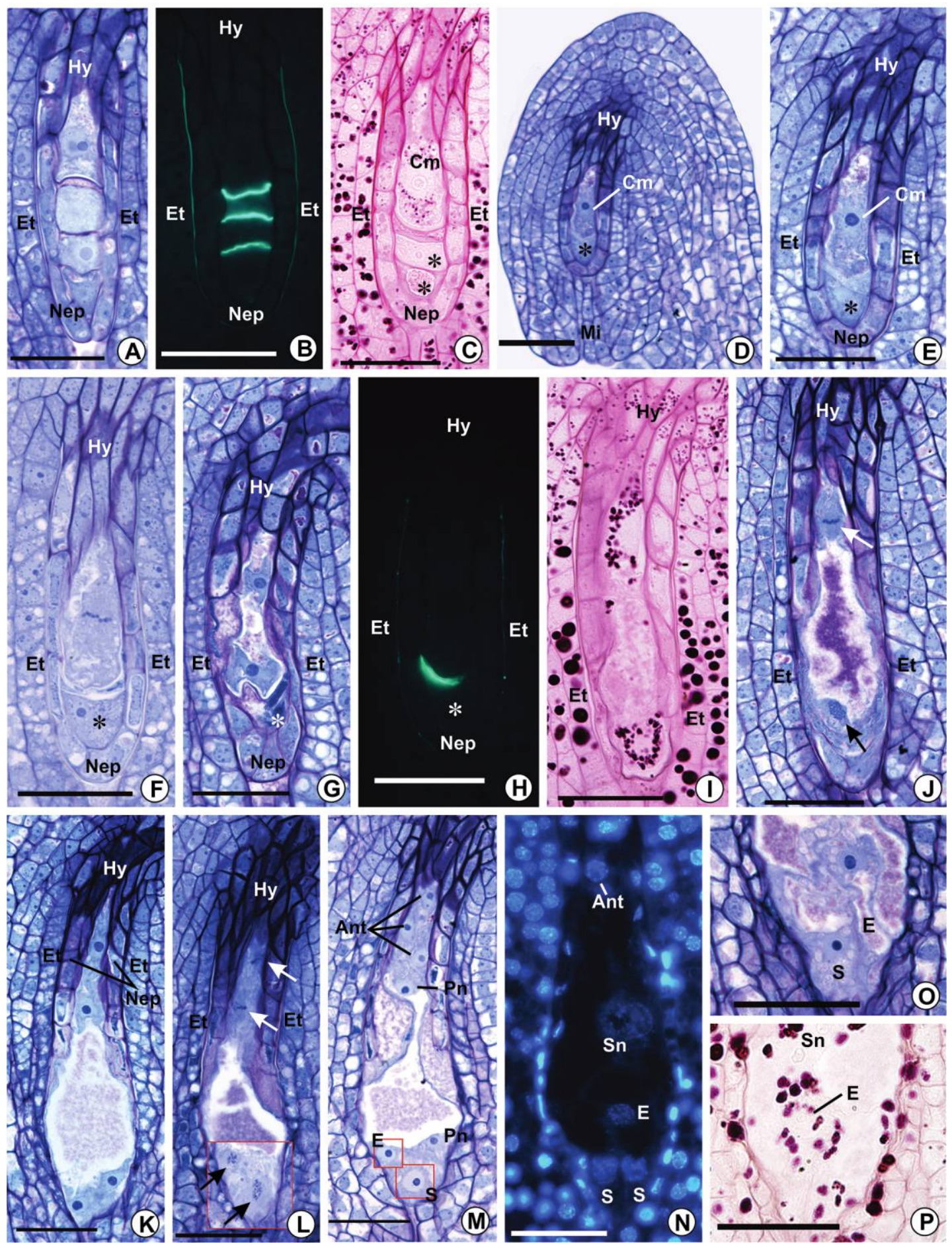

Fig. 7 Megagametogenesis in Cybistax antisyphilitica. Longitudinal sections of developing ovules. A, B, Linear tetrad of megaspores. $B$, Callose in the tetrad transverse walls. $C$, Early stage of the uninucleate megagametophyte. $D, E$, Late uninucleate megagametophyte. Asterisk indicates the degenerated micropylar megaspores. F, First acytokinetic mitosis in the megagametophyte. $G-I$, Binucleate megagametophyte. $H$, Callose cap at the distal end of the megagametophyte. J, Second cycle of karyokinesis in the megagametophyte. Arrows point to metaphase plates. $K$, Tetranucleate stage of the megagametophyte. $L$, Last mitotic cycle in the megagametophyte. Arrows indicate metaphase plates. $M$, Cellularization in the chalazal pole of an octonucleate megagametophyte. $N-P$, Mature megagametophytes. N, Nuclei organization in the mature megagametophyte. $O, P$, Egg apparatus. Ant = antipodes, $\mathrm{CC}=$ central cell, $\mathrm{Cm}=$ chalazal megaspore/uninucleate megagametophyte, $\mathrm{E}=$ egg cell, $\mathrm{Et}=$ endothelium, $\mathrm{Fa}=$ filiform apparatus, $\mathrm{Hy}=$ hypostase, $\mathrm{Mi}=$ micropyle, $\mathrm{Nep}=$ nucellar epidermis, $\mathrm{Pn}=$ polar nucleus, $\mathrm{S}=$ synergids, $\mathrm{Sn}=$ secondary nucleus. Staining: toluidine blue $\mathrm{O}(A, D-G, J-M, O)$, aniline blue $(B, H)$, periodic acid-Schiff $(C, I, P), 4^{\prime}, 6-$ diamidino-2-phenylindole $(N)$. Scale bars $=30 \mu \mathrm{m}$. 


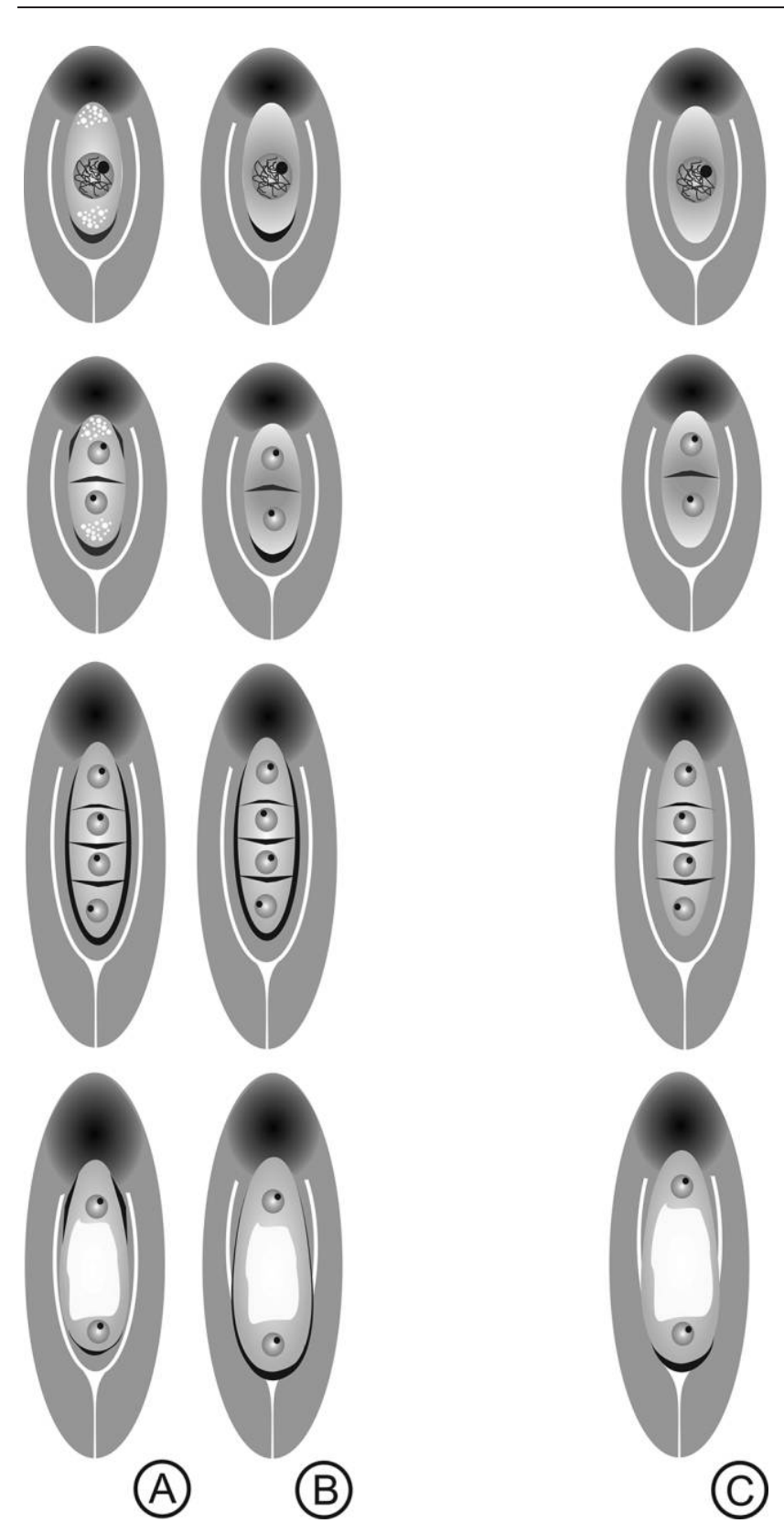

octonucleate embryo sac. The metaphase plate of the first acytokinetic division in the uninucleate megagametophyte is perpendicular to the longitudinal axis of the ovule (figs. 5C, $7 F$ ). The two resulting nuclei move apart from each other toward opposite poles of an elongating coenocytic megagametophyte. At this stage, a large vacuole occupies the space between the two nuclei, and a smaller vacuole is also present in the chalazal pole of the megagametophyte between the chalazal nucleus and the wall facing the hypostase. Both vacuoles contain the same granular substance observed in the previous stages, which is PAS positive and stains reddish purple with toluidine blue $\mathrm{O}$ (figs. $3 F, 5 E, 5 F, 7 G, 7 I$ ). This content also appears to be the same as in vacuoles of somatic cells of the ovule, and it was found in all of the subsequent stages of female gametophyte development. Amyloplasts appear around both nuclei of the binucleate megagametophyte (figs. 5E, 7I). Remnants of the degenerate nonfunctional megaspores are squeezed at the micropylar end of the megagametophyte (figs. 5D-5F, 7G).

Cells of the nucellar epidermis start to show signs of degeneration - such as nuclear pyknosis, plasmolysis, and cytoplasmic coagulation - and finally collapse (figs. $3 F, 5 F, 7 G$ ), except for those around the chalazal portion of the megagametophyte, which may show protoplasmic degradation but usually maintain their original form in subsequent stages (figs. $3 F-3 L$, $5 G-5 L, 7 G-7 M)$. Although these features of the degenerative process are clearly evident from the binucleate stage of the coenocytic embryo sac onward, in several ovules they appeared even in earlier stages (figs. $2 \mathrm{~K}, 2 \mathrm{P}, 3 \mathrm{~A}, 4 \mathrm{~L}, 4 \mathrm{P}, 4 \mathrm{Q}, 5 \mathrm{~A}, 5 \mathrm{C}$, $7 F)$. During their degenerative process, the cells of the nucellar epidermis accumulate a secretion with the same staining properties as the vacuole content between the collapsing protoplast and the cell wall. The secretion is subsequently released into the micropylar canal and around the megagametophyte, next to the degenerated nonfunctional megaspores (fig. 7G). The walls of collapsed cells of the nucellar epidermis remain around the micropylar portion of the binucleate megagametophyte, separating it from the integument (figs. $3 F, 3 G, 5 G, 7 I, 7 J$ ).

In the three species, the developing embryo sac continues to expand, and the second acytokinetic mitotic cycle of megagametogenesis occurs simultaneously in the micropylar and chalazal nuclei of the megagametophyte (figs. $3 G, 5 G, 7 J$ ). The metaphase plate of the chalazal nucleus is perpendicular or oblique to the megagametophyte longitudinal axis; on the other hand, the metaphase plate of the micropylar nucleus is parallel or oblique to the axis (figs. $3 G, 5 G, 7 J$ ). After karyokinesis, the two chalazal nuclei move away from each other along the longitudinal axis of the megagametophyte, while the micropylar nuclei aligns approximately perpendicular to this longitudinal axis. The micropylar portion of the megagametophyte expands laterally and toward the micropyle, invading areas that were previously occupied by amyloplast-rich cells that degenerated (after showing cytoplasm coagulation and karyopyknosis) and collapse, while the megagametophyte as a whole becomes club shaped (figs. $3 \mathrm{H}, 5 \mathrm{H}, 7 \mathrm{~K}$ ). As observed for the nucellar epidermis, remnants of the walls of cells located around the inner end of the micropylar canal also remain around the micropylar extended portion of the megagametophyte, forming a pectocellulosic envelope that persists until the mature megagametophyte stage (figs. $3 H-3 L, 5 I-5 L$, $7 K-7 M)$. 
A large number of conspicuous starch grains persist even after the degeneration and collapse of the cells at the inner end of the micropyle. These amyloplasts accumulate around the megagametophyte envelope, giving the envelope a wavy contour (figs. $5 \mathrm{~L}, 5 \mathrm{O}, 7 \mathrm{P}$ ). In the preanthesis stage, amyloplasts surrounded all of the nuclei of the mature megagametophyte (figs. 3J, 3M, 5L, 5O, 7P).

As during the second cycle, the third and last cycle of mitotic division also occurs simultaneously in the nuclei of both the micropylar and the chalazal poles of the coenocytic embryo sac. In both poles, the orientation of the nuclei metaphase plates tended to be perpendicular to each other, approaching a characteristic $\mathrm{T}$ configuration, although the chalazal pair showed an inverted position relative to the micropylar pair (fig. $5 J$ ). Furthermore, the metaphase plate of the distal nucleus in the chalazal pair and that of the proximal nucleus in the micropylar pair approached a transverse position (i.e., perpendicular to the longitudinal axis of the megagametophyte; fig. $5 J$ ). However, deviations from this configuration pattern were sometimes observed (fig. $7 L$ ).

The transition from the late tetranucleate to the octonucleate coenocytic phase seems to be quickly followed by cellularization because ovules containing noncellularized octonucleate embryo sacs were rarely observed. At this transient stage, after cytokinesis, the proximal mitotic nucleus of the chalazal pole generates the nuclei of two antipodal cells, and the distal nucleus generates the nucleus of a third antipodal cell and the chalazal polar nucleus of the central cell (fig. 7M). At the micropylar pole, the distal mitotic nucleus originates the nuclei of two synergids, and the proximal nucleus generates the micropylar nucleus of the central cell and the egg cell nucleus (fig. $7 \mathrm{M}$ ). Therefore, after the last mitotic cycle, the megagametophyte has eight nuclei and seven cells (figs. $3 I-3 M, 5 K-5 O, 7 M-$ $7 P$ ). To some extent, for all species, the mature female gametophyte and those of previous stages showed a characteristic secretion accumulation in its middle portion between the integument/collapsed nucellar epidermis and the megagametophyte wall, although this pattern was more pronounced in Cy. antisyphilitica, where the embryo sac lateral walls are displaced from remnants of the degenerate nucellar epidermis/endothelial cells, giving an hourglass shape to this region (fig. $7 \mathrm{~L}, 7 \mathrm{M}$ ).

The cellularization process appears to be faster in the chalazal region because in megagametophytes in which the cell walls of the egg apparatus are not yet evident, the thin walls that separate the antipodals are already present (fig. $7 \mathrm{M}$ ). The antipodals contain dense cytoplasm and may contain small vacuoles (figs. $3 \mathrm{~L}, 5 \mathrm{~K}$ ). These cells may organize themselves in a linear or a triangular arrangement, sometimes showing small amyloplasts. The chalazal polar nucleus starts migrating toward the central area of the megagametophyte before the complete cellularization of the antipodals.

After cellularization, enlargement of cells of the egg apparatus (cf. fig. $7 \mathrm{M}, 7 \mathrm{O}$ ) and the migration of the two polar nuclei to a central position in the embryo sac are the most remarkable features of the last steps of female gametophyte maturation. In the mature megagametophyte, the egg cell usually acquires an elongated pear shape, with a large vacuole in two-thirds of the micropylar portion of the cytoplasm and the nucleus surrounded by small vacuoles and amyloplasts at the enlarged chalazal end of the cell (figs. $3 L, 5 N, 7 O$ ). The synergids are hooked and also pear shaped, wide at the chalazal end and narrow at the micropylar end (figs. $3 K, 5 K, 5 O$ ). Each synergid contains its nucleus at the micropylar pole or at a central-micropylar position and a conspicuous vacuole at the chalazal pole of the cytoplasm, with some small, rounded vacuoles often appearing between the nucleus and the pointed micropylar end of the cell (figs. $3 K, 5 K$ ).

The large central cell comprises most of the mature megagametophyte volume and contains amyloplasts in the cytoplasm, especially around the polar nuclei (figs. 3I, 3J, 5K, $5 \mathrm{~L}$ ). The central cell has a wide vacuole with a faintly PASpositive granulated content that also stains reddish-purple with toluidine blue $\mathrm{O}$ (figs. $3 \mathrm{I}, 3 \mathrm{~J}, 5 \mathrm{~K}, 5 \mathrm{~L}$ ). During its expansion, the egg apparatus invades the micropylar region of the central cell, such that a narrow space, which is filled by the central cell cytoplasm, remains between the embryo sac envelope and the lateral sides of the egg apparatus (figs. $3 \mathrm{~J}, 5 \mathrm{~K}$ ). Thus, the egg apparatus is in direct contact with the embryo sac envelope only at the micropylar end. The two polar nuclei fuse to form the secondary nucleus (figs. $5 \mathrm{M}, 7 \mathrm{~N}$ ). The filiform apparatus originates from the walls between the micropylar ends of the two synergids; this apparatus stains reddish purple with toluidine blue $\mathrm{O}$ and is PAS positive (figs. $3 \mathrm{M}, 5 \mathrm{~K}, 5 \mathrm{O}$ ). The synergids persist until the early stages of endosperm development in fertilized embryo sacs (not shown). The events of megasporogenesis and megagametogenesis show no synchrony among the ovules of the same ovary.

\section{Discussion}

The three species investigated in this study have bicarpellate syncarpous gynoecia, as is common for all of the Bignoniaceae. The presence of two placental ridges per carpel-from which the ovules emerge, as observed in the species investigated here-is also a characteristic feature of the gynoecium in the Bignoniaceae (Leinfellner 1973). However, while these placental ridges are displayed on both faces of the septum in the eusyncarpous ovary of Cybistax antisyphilitica and Tabebuia roseoalba, in Crescentia cujete, the placental ridges are displayed on the internal face of the ovary wall because of its paracarpous condition. As is common for other asterid taxa, the Bignoniaceae has a completely syncarpous gynoecium whose relatively long symplicate zone (and compitum) take up the entire style and at least the uppermost part of the ovary (Endress 1994). In the tribe Crescentieae, there are several intermediate conditions between the ancestral eusyncarpous constitution and the paracarpous ovary with parietal placentation, and this diversity in carpellary organization is also found in the Paleotropical tribe Coleeae (Gentry 1980). However, on the basis of an almost completely symplicate gynoecium in C. cujete, which shows only a short sterile synascidiate zone at the base of its unilocular ovary, Leinfellner (1973) concluded that Crescentia is the unique genus in Bignoniaceae, with a true parietal placentation.

The derivation of paracarpy and intermediate forms from the ancestral eusyncarpous condition of the ovary in Bignoniaceae could be explained by different degrees of reduction of the synascidiate zone and a reciprocal increase of the symplicate zone that is involved in the ovary construction, combined with changes in vascularization, although additional 
studies are needed to confirm this hypothesis. However, our observations and the current data concerning the evolution of syncarpy and placentation in the Bignoniaceae indicate that ovaries with some degree of a symplicate paracarpious zone evolved independently in Coleeae and Crescentieae from synascidiate eusyncarpous ancestors.

The placentae and ovule primordia of the three species in the early stages of ovary development show a tunica-corpus organization, according to the histological zonation described by Bouman $(1974,1984)$, who traced a parallel between the cellular organization of apical meristems and the ovule primordium. In the ovule primordia of all species investigated in this study, the tunica is composed of an epidermal layer with only anticlinal cell divisions and a subepidermal layer that usually shows anticlinal cell divisions but in which oblique and periclinal divisions eventually occur. The corpus corresponds to the central region and does not have a regular pattern of cell divisions. Only two studies investigated the histological organization of the ovule primordium in the Bignoniaceae: Galati and Strittmatter (1999) reported a bizonate ovule primordium in Jacaranda mimosifolia, and Bittencourt and Mariath (2002b) observed a trizonate ovule primordium in Handroanthus pulcherrimus. Bouman (1984) pointed out that a bizonate ovule primordium initiates by periclinal divisions in the subepidermal layer of the placenta, and this type of primordium appears to be smaller than a trizonate primordium, with an epidermal layer whose cells divide only anticlinally. On the other hand, a trizonate ovule primordium usually initiated by periclinal divisions in the central region (corpus) of the placental meristem, while cells of the two outer layers divide anticlinally (Bouman 1984). Although J. mimosifolia belongs to a clade that has been recognized as the sister group for the rest of the Bignoniaceae (Olmstead et al. 2009), because of the scarcity of studies, it is not possible to determine whether the bizonate ovule is a plesiomorphic condition in the family or whether it evolved independently within Jacaranda.

The number of ovules per locule is a characteristic with taxonomic relevance (Gentry 1980), and this trait was one of the morphological characters used to separate Handroanthus, which has eight to 10 ovules per locule, from Tabebuia, which has three to four ovules per locule (Mattos 1970; Grose and Olmstead 2007b). However, T. roseoalba (this study), Tabebuia rosea, and Stereospemum chelonoides (Mehra and Kulkarni 1985) show only two rows of ovules per locule. The presence of only two ovules versus eight to 12 ovules per locule (half of the ovules in each carpel placental ridge) in a transverse section of the ovary in T. roseoalba and Cy. antisyphilitica not only corroborates the Mattos (1970) segregation but also extends the distinctive condition (relative to Tabebuia s.s.) of more than three to four ovules per locule to other taxa of the Bignoniaceae with a bicarpellate-eusyncarpous ovary.

The archesporial region of the nucellus in T. roseoalba (i.e., the archesporial cell plus the nucellar epidermis) is inconspicuous and becomes prominent only at later stages of MMC development, probably because of space limitation in the locular cavity, which differs from Cy. antisyphilitica, C. cujete, and other taxa belonging to the internal clades of the Tabebuia alliance, in which there is an open space (a broad locular cavity) between the ovary wall and the ovule primordia and the nucellus is ab initio protruding (Johri et al. 1992; Bittencourt and Mariath 2002b). The nonprotruding nucellus in early stages of the archesporium/MMC development in T. roseoalba also appears to be related to the number of ovules per locule in a cross section of the ovary because eight to 10 ovules per locule have been reported for Handroanthus and other species with a bicarpellate-eusyncarpous gynoecium, and only two to four ovules per locule have been reported in Tabebuia s.s. (this study; Mattos 1970; Grose and Olmstead 2007b). Preliminary observations in $T$. rosea-a species that originally occurred from Southern Mexico to Venezuela and coastal Ecuador (Gentry 1992) but is now cultivated in many places worldwide in the tropics - also indicated the occurrence of a nonprotruding nucellus in the young ovules that emerges in only two series per carpel (N. S. Bittencourt Jr., unpublished data), as observed in $T$. roseoalba. Therefore, the nonprotruding nucellus in the initial stages of ovule development may be a synapomorphic character state of the young ovule for Tabebuia, although additional studies of other taxa in the Tabebuia alliance are needed to confirm this hypothesis.

The ovule in C. cujete, T. roseoalba, and Cy. antisyphilitica is anatropous, unitegmic, and tenuinucellate. The same features were observed in J. mimosifolia (Galati and Strittmatter 1999), H. pulcherrimus (Bittencourt and Mariath 2002b), and most of the species of Bignoniaceae (Davis 1966; Johri et al. 1992). Hemianatropous ovules were noticed in $S$. chelonoides and Millingtonia hortensis (Mehra and Kulkarni 1985). A few hemianatropous ovules were observed in Oroxylum indicum, although most ovules in this species are anatropous (Ghatak 1956). Kigelia africana (syn. Kigelia pinnata) and Parmentiera cereifera occasionally show hemianatropous ovules (Gonvidu 1950). Bouman and Schier (1979) pointed out that in unitegmic sympetalous plants, the integument does not always have an exclusively epidermal origin, but it can also be derived partially from the subepidermal layer. In fact, unitegmy evolved several times in angiosperm history, and the single integument does not correspond to an outer or an inner integument but is a complex structure in which both layers take part and cannot be distinguished morphologically (Bouman and Calis 1977; Endress 2011). The integument in the three species studied here initiates from the epidermal layer via periclinal divisions. However, shortly after the first divisions of epidermal cells, periclinal divisions also occur in the subepidermal layer and push the cells of epidermal origin to the top of the nucellus. This phenomenon was named integumentary shifting by Bouman and Calis (1977). Handroanthus pulcherrimus shows the same developmental pattern (Bittencourt and Mariath 2002b). Galati and Strittmatter (1999) described a different pattern for $J$. mimosifolia, in which only the dermal layer participates in integument development. Because in recent phylogeny studies, the tribe Jacarandeae appears as sister to the rest of the family (Spangler and Olmstead 1999; Grose and Olmstead 2007a; Olmstead et al. 2009), it is possible that the epidermal origin (zone 1 only) of the integument is a plesiomorphic condition in Bignoniaceae from which the epidermal + subepidermal origin derivates. However, Galati and Strittmatter (1999) did not present any comment on the pattern of division in the subepidermal cells immediately below the group of cells of epidermal (zone 1) origin; thus, a reevaluation of the integument ontogeny in J. mimosifolia and additional investigations in other species of Jacarandeae and the closest external groups 
of the Bignoniaceae are necessary to test the hypothesis of plesiomorphy of the exclusive epidermal origin of the integument in Bignoniaceae.

In the three species studied here, the micropyle begins to be organized during the tetrad stage, as reported for M. hortensis, Fernandoa adenophylla (syn. Heterophragma adenophyllum; Mehra and Kulkarni 1985), and H. pulcherrimus (Bittencourt and Mariath 2002b). However, some variations in the point of ovule development at which the micropyle begins to be formed appear to occur between species in the Bignoniaceae, as this event was reported to occur in the MMC stage in T. rosea, S. chelonoides, and Dolichandrone falcata (Mehra and Kulkarni 1985) and when the MMC undergoes meiosis in J. mimosifolia (Galati and Strittmatter 1999). Unfortunately, other embryological studies in the Bignoniaceae do not supply information concerning the ovule developmental stage at which micropyle organization occurs.

The hypostase is a common trait in Bignoniaceae (Gonvidu 1950; Ghatak 1956; Galati and Stritttmatter 1999). In some studies, this tissue has been viewed as being involved in the inhibition of aggressive growth of the endosperm haustorium in the chalazal portion of the developing seed (Mehra and Kulkarni 1985). In J. mimosifolia, abundant insoluble polysaccharides are present in hypostase cell walls, suggesting the role of this tissue in carbohydrate reserve during endosperm development (Galati and Strittmatter 1999). The staining properties of these cells in all species here investigated indicate not only the polysaccharide richness of their walls but also the polysaccharide nature of their vacuolar content. In fact, many authors believe that the main function of the hypostase is to supply nutrients for the megagametophyte, although those authors disagree about the mechanisms by which this process occurs (Tilton 1980; Boesewinkel and Bouman 1984; Batygina and Shamrov 1999). The hypostase in the Bignoniaceae persists until the advanced stages of the megagametophyte and may continue to develop and differentiate during the early stages of endosperm development (Bittencourt and Morais 2010). This tissue originates adventitious embryo precursor cells in sporophytic apomictic species of Handroanthus (Costa et al. 2004; Souza et al. 2005; Bittencourt and Moraes 2010) and Anemopaegma (Sampaio et al. 2013a, 2013b). No differences in the features of the hypostase were found among the three species here investigated.

MMC meiosis in Cy. antisyphilitica originates only linear tetrads of megaspores, and the chalazal megaspore gives rise to a monosporic Polygonum-type megagametophyte, as in other previously studied species in the Bignoniaceae (Gonvidu 1950; Ghatak 1956; Davis 1966; Mehra and Kulkarni 1985; Johri et al. 1992; Galati and Strittmatter 1999; Souza et al. 2005; Renó et al. 2007; Sampaio 2007; Souza et al. 2008), including H. pulcherrimus (Bittencourt and Mariath 2002a). The same pattern was observed in C. cujete and T. roseoalba, but although linear tetrads predominate, a small percentage of young ovules with T-shaped tetrads were observed in these species. Although there is evidence for the phylogenetic relevance of megaspore tetrad patterns in some taxa (Rembert 1972), in the few studies of Bignoniaceae that investigated this issue, no information was given about the number of samples observed to classify the megaspore tetrad arrangement. Linear tetrads are reported for nearly all species in these studies (Duggar 1899; Govindu 1950; Ghatak 1956; Mehra and Kul- karni 1985), but T-shaped tetrads (except for one case of an isobilateral tetrad) were noticed in K. africana (Govindu 1950), and linear and T-shaped tetrads were found in J. mimosifolia (Galati and Strittmatter 1999). In spite of the putative typical presence of T-shaped tetrads during megasporogenesis in K. africana, on the basis of the present observations as well as observations of other previously studied bignoniaceous speciessuch as Handroanthus ochraceus, Handroanthus chrysotrichus, and Spathodea campanulata (N. S. Bittencourt Jr., unpublished data) - we assume that the occurrence of T-shaped tetrads in the Bignoniaceae may be purely occasional and scattered throughout the family.

In C. cujete and T. roseoalba, during meiosis, callose deposition was observed in the walls of the micropylar portion of the MMC during prophase/metaphase I. This observation constitutes a peculiar feature that was not reported for any other previously investigated species in the Bignoniaceae. Callose also occurs in the transverse cell walls of dyads and tetrads in all species and probably favors chalazal megaspore development due the difficulty of translocating nutrients to micropylar megaspores (Kapil and Tiwari 1978). In the ovule, callose deposition may work like a molecular or nutritional filter by decreasing the permeability of the cell wall and promoting a temporary isolation of the megaspores, which enables them to embark upon independent courses of development (Rodkiewiez 1970; Bouman 1984).

The position of the functional megaspore close to the chalaza is a positive factor for its development due to the nutritional role of the hypostase and the connection of the hypostase to the funicular provascular bundle tip, as reported by Bittencourt and Mariath $(2002 b)$ for $H$. pulcherrimus. In most angiosperms with a Polygonum-type ontogeny, callose is laid down first on the chalazal pole of the MMC wall at the onset of meiosis, followed by its temporary deposition around the entire megasporocyte and its subsequent disappearance from the chalazal pole (Rodkiewicz 1970; Kapil and Tiwari 1978). However, in the present study, callose deposition was observed only on the micropylar pole of the megasporocyte cell wall in both C. cujete and T. roseoalba and was never observed before the dyad stage in Cy. antisyphilitica.

The presence of callose in part of the proximal half of the chalazal cell wall of the dyad in T. roseoalba is a feature that has not been reported for other members of the family and is potentially apomorphic at the species or genus level, although further studies are needed to confirm this hypothesis. The pattern of callose distribution that was observed in T. roseoalba megaspore tetrads also occurs in Handroanthus pulcherimus (Bittencourt and Mariath 2002b) but not in Cy. antisyphilitica, which points to a closer relationship between Tabebuia and the clade to which Crescentia and Handroanthus belong. The callose hood that results from the superposition of wall remnants of the collapsed micropylar megaspores remains at least up to the uninucleate stage of embryo sac development in all of the plants under study, but this hood appears to disappear more quickly in T. roseoalba. The same phenomenon was reported for $H$. pulcherrimus (Bittencourt and Mariath 2002b). Crescentia cujete is the only species investigated to date to also have callose on the lateral walls of one- to two-nucleated megagametophytes.

Kapil and Tiwari (1978) defined the endothelium as the inner epidermis of the inner integument in bitegmic ovules or the in- 
ner epidermis of the single integument in unitegmic ovules. Endress (2010) reported the presence of an endothelium in the majority of the Lamiales taxa. Usually, the cells of this tissue are radially or tangentially elongated and have a dense cytoplasm and prominent and often polyploid nucleus (Kapil and Tiwari 1978). The endothelium in the three species studied here is not so evident as it typically appears in ovules of other taxa (Kapil and Tiwari 1978). However, it was recognized here as one to three layers of integumentary cells in contact with the external face of the nucellar epidermis and next to the proximal portion of the developing megegametophyte. This cells showed dense cytoplasm, high nucleus/cytoplasm ratio and prominent nucleoli, and often they appeared as tangentially or radially elongated cells. Despite showing only a discrete differentiation relative to the outer layers of the ovule integument, the endothelium has been reported for many bignoniaceous species scattered throughout the family (Govindu 1950; Ghatak 1956; Mehra and Kulkarni 1985; Galati and Strittmatter 1999; Bittencourt and Mariath 2002b), and it continues to expand and differentiate around the endosperm, during the development of the seed (Bittencourt and Moraes 2010; Sampaio et al. 2013). The endothelium canalizes nutrients to the developing megagametophyte (Kapil and Tiwari 1978), and the occurrence of a large number of amyloplasts in the endothelium and other cells of the inner layers of the integument, as observed here, is consistent with this role. No differences in the general features of the endothelium were observed between species in this study.

The onset of amyloplast formation in the ovule appears to vary not only with respect to the ovule developmental stage but also with respect to the tissue in which it occurs, appearing throughout the ovule in the archesporium stage in T. roseoalba, in the chalaza, nucellar epidermis and integument in the MMC PCD stage in C. cujete and Cy. antisyphilitica (this study), and in the endothelium during meiosis in $H$. pulcherrimus (Bittencourt and Mariath 2002b). Because amylogenesis was not analyzed in other studies of ovule ontogeny in the Bignoniaceae, it is not possible at this point to attribute any systematic significance to the timing of amyloplast formation onset in ovule development in Bignoniaceae. According to Tilton and Lersten (1981), starch may begin to accumulate in the megagametophyte as early as the MMC stage or only in the stages immediately prior to fertilization, but starch is usually present by the time the megagametophyte is cellular and reaches a maximum shortly after fertilization. In fact, in this study, amyloplasts reached their largest number and size immediately before megagametophyte maturity for all species. This feature appears to be a common trait in Bignoniaceae, with C. cujete, Cy. antisyphilitica and T. roseoalba showing amyloplasts in all cells of the egg apparatus, as described for H. pulcherrimus (Bittencourt and Mariath 2002a).

From the binucleate stage on, the megagametophyte gradually becomes club-shaped due to the expansion of the diameter and length of its distal portion, which invades regions originally occupied by cells of the inner layers of the integument. The degeneration of these cells always follows the degeneration of the nucellar epidermis in the same area, and this phenomenon may be causally related to the expansion of the developing megagametophyte. The same phenomenon has been noticed in many species of Bignoniaceae (Mauritzon 1935; Swamy 1941; Govindu 1950; Ghatak 1956; Mehra and Kulkarni 1985; Galati and Strittmatter 1999). Some of those authors suggested that the degeneration and collapse of the nucellar epidermis and integument cells are consequences of an aggressive expansion of the megagametophyte. However, accurate examinations of our own sections indicate that cell degeneration in the nucellar epidermis and integument appears to be the culmination of an apoptotic process because the observed collapse was preceded by nuclear pyknosis, cytoplasm coagulation and plasmolysis. These signs of the degenerative process appeared sequentially in the nucellar epidermis and integument cells, with megagametophyte expansion following the cell collapse in these tissues, which may indicate a molecular cross talk between the developing embryo sac and the surrounding somatic tissues that triggers their apoptosis.

In this study, cells of the nucellar epidermis and the endothelium that are in contact with the micropylar portion of the expanding megagametophyte appeared to be involved in a holocrine secretion process that is related to nutrient supply and increasing the space necessary for normal megagametophyte development. From the tetranucleate stage onward, the secretion accumulates around the middle region of the megagametophyte, causing its wall to separate from the degenerating nucellar epidermis/integument cells and forming a bottleneck in this region. This phenomenon is particularly evident in Cy. antisyphilitica. The accumulation of this secretion around the median portion of the megagametophyte has not been reported for other species of Bignoniaceae, and this study appears to be the first report of the participation of the nucellar epidermis and integument in a holocrine secretion process that favors angiosperm female gametophyte development. The secretion has a PAS-positive granulated appearance and stains reddish purple with toluidine blue $\mathrm{O}$. These features are similar to those observed for the vacuole content of the megagametophyte cells in virtually all stages of development, as well as for some cells of the surrounding sporophytic tissues.

In all of the plants studied here, a Polygonum-type megagametophyte with eight nuclei and seven cells is formed after three successive mitotic cycles. The events of protoplasm vacuolization, nuclear migration and spindle positioning that were verified in this study during the coenocytic embryo sac development are nearly identical to those described for $H$. pulcherrimus (Bittencourt and Mariath 2002a). At the time of megagametophyte maturity, the egg apparatus has a hooked configuration, with only the micropylar portion of the synergids and the egg cell walls in direct contact with the embryo sac envelope. Such features were also reported for other Bignoniaceae and appear to be common for all members of the family (Mauritzon 1935; Swamy 1941; Gonvidu 1950; Ghatak 1956; Davis 1966; Mehra and Kulkarni 1985; Johri et al. 1992; Bittencourt and Mariath 2002a). The egg cells of the three species show a polarized cytoplasm with a morphologically evident apical-basal axis, corresponding, respectively, to the future shoot-root axis of the embryo. The nucleus is positioned at the apical (chalazally oriented) end, and a large vacuole occupies the basal (micropylarly oriented) end. This pattern is present in most flowering plants (Zhang and Laux 2011; Lau et al. 2012). The polarity of the egg cell could be a product of the chalazal-micropylar axis organization of the surrounding maternal tissues (Ueda and Laux 2012), although apomictic embryos showing inverted polarity have been found 
in polyembryonic seeds of agamic complexes in Bignoniaceae (Bittencout and Moraes 2010; Sampaio et al. 2013b). The zygote appears to conserve a similar cytoplasmic polarity, with a nucleus at the chalazal pole and a large vacuole at the micropylar pole, as reported for several other members of Bignoniaceae, such as S. campanulata (Bittencourt et al. 2003), T. roseoalba (Gandolphi and Bittencourt 2010), H. chrysotrichus, H. ochraceus (Bittencourt and Moraes 2010), and Cy. antisyphilitica (Bittencourt et al. 2011).

\section{Concluding Remarks}

Although it is clear that embryological characteristics are notably conserved in Bignoniaceae, our study revealed several new and relevant features related to the embryology of the family. Some of those have potential systematic significance, such as the number and orientation of ovules in transverse sections of the ovary, the pattern of nucellus emergence (protruding vs. nonprotruding) in the young ovule and particularly, the patterns of callose wall deposition during megasporogenesis, which point to the existence of closer phylogenetic relationships among Crescentia, Handroanthus, and Tabebuia in comparison to Cybistax. The nonprotruding early nucellus appears to be correlated with the reduced number of ovule series on the placental column. It may be useful for separating Tabebuia from the other taxa in the Tabebuia alliance. Our study also shows that the optimization of embryological characters and character states in phylogenetic trees of the Bignoniaceae is remarkably limited not only by the paucity of studies in different taxa but also by the incomplete characterization of ovule ontogeny in many previous investigations and the varied approaches of their authors.

\section{Acknowledgments}

We are grateful to Coordenação de Aperfeiçoamento de Pessoal de Nível Superior for a research scholarship granted to E. J. Pereira Jr. and to Fundação de Amparo à Pesquisa do Estado de São Paulo for financial support.

\section{Literature Cited}

Anderson GJ, SD Johnson, PR Neal, G Bernardello 2002 Reproductive biology and plant systematics: the growth of a symbiotic association. Taxon 51:637-653.

Arango-Ulloa J, A Bohorquez, MC Duque, BL Maass 2009 Diversity of the calabash tree (Crescentia cujete L.) in Colombia. Agrofor Syst 76:543-553.

Batygina TB, II Shamrov 1999 New approach to interpreting the ovular basic structures. Phytomorphology 49:223-231.

Berg RY 2009 Embryo sac, endosperm, and seed of Nemophila (Boraginaceae) relative to taxonomy, with a remark on embryogeny in Pholistoma. Am I Bot 96:565-579.

Bittencourt NS Jr, PE Gibbs, J Semir 2003 Histological study of post-pollination events in Spathodea campanulata Beauv. (Bignoniaceae), a species with late-acting self-incompatibility. Ann Bot 91:827-834.

Bittencourt NS Jr, JEA Mariath 2002a Ovule ontogeny of Tabebuia pulcherrima Sandwith (Bignoniaceae): embryo sac development. Rev Bras Bot 25:117-127.

$2002 b$ Ovule ontogeny of Tabebuia pulcherrima Sandwith (Bignoniaceae): megasporogenesis and integument development. Rev Bras Bot 25:103-115.

Bittencourt NS Jr, CIG Moraes 2010 Self-fertility and polyembryony in South American yellow trumpet trees (Handroanthus chrysotrichus and $H$. ochraceus, Bignoniaceae): a histological study of postpollination events. Plant Syst Evol 288:59-76.

Bittencourt NS Jr, EJ Pereira Jr, PS São Thiago, J Semir 2011 The reproductive biology of Cybistax antisyphilitica (Bignoniaceae), a characteristic tree of the South American savannah-like "Cerrado" vegetation. Flora 206:872-886.

Boesewinkel FD, F Bouman 1984 The seed: structure. Pages 567610 in BM Johri, ed. Embryology of angiosperms. Springer, Berlin. Bouman F 1974 Developmental studies of the ovule integuments and seed in some angiosperms. PhD diss. University of Amsterdam.

1984 The ovule. Pages 123-157 in BM Johri, ed. Embryology of angiosperms. Springer, Berlin.

Bouman F, JIM Calis 1977 Integumentary shifting - a third way to unitegmy. Ber Dtsch Bot Ges 90:15-28.

Bouman F, S Schier 1979 Ovule ontogeny and seed coat development in Gentiana, with a discussion on the evolutionary origin of the single integument. Acta Bot Neerl 28:467-478.
Costa ME, DS Sampaio, AAS Paoli, SCAL Leite 2004 Poliembrionia e aspectos da embriogênese em Tabebuia ochracea (Chamisso) Standley (Bignoniaceae). Rev Bras Bot 27:395-406.

Davis OL 1966 Systematic embryology of the angiosperms. Wiley, New York.

De Candolle AP 1838 Revue sommaire de la famille des Bignoniacées. Bibliothèque Universelle de Genève, Geneva.

Duggar BM 1899 On the development of the pollen grain and embryo sac in Bignonia venusta. Bull Torrev Bot Club 26:89-105.

Endress PK 1994 Floral structure and evolution of primitive angiosperms: recent advances. Plant Syst Evol 192:79-97.

2010 Flower structure and trends of evolution in eudicots and their major subclades. Ann Mo Bot Gard 97:541-583.

2011 Angiosperm ovules: diversity, development, evolution. Ann Bot 107:1465-1489.

Erbar C, C Gülden 2011 Ontogeny of the flowers in Paulownia tomentosa - a contribution to the recognition of the resurrected monogeneric family Paulowniaceae. Flora 206:205-218.

Eschrich W, HB Currier 1964 Identification of callose by its dichrome and fluorochrome reactions. Stain Technol 39:303-307.

Galati BG, LIStrittmatter 1999 Ovule ontogeny and megasporogenesis in Jacaranda mimosifolia D. Don. (Bignoniaceae). Phytomorphology 49:67-74.

Gandolphi G, NS Bittencourt Jr 2010 Sistema reprodutivo do ipêbranco: Tabebuia roseo-alba (Ridley) Sandwith (Bignoniaceae). Acta Bot Bras 24:840-851.

Gentry AH 1969 Tabebuia: the tortuous history of a generic name (Bignon.). Taxon 18:635-642.

1972 Handroanthus (Bignoniaceae): a critique. Taxon 21: 113-114.

1980 Bignoniaceae. I. Crescentieae and Tourrettieae. Flora Neotropica Monograph 25. New York Botanical Garden Press, Bronx, New York.

1992 Bignoniaceae. II. Tribe Tecomeae. Flora Neotropica Monograph 25. New York Botanical Garden Press, Bronx, New York.

Ghatak J 1956 A contribution to the life history of Oroxylum indicum Vent. Proc Indian Acad Sci B 43:72-87.

Govindu HC 1950 Studies in the embryology of some members of Bignoniaceae. Proc Indian Acad Sci B 32:164-178. 
Grose SO, RG Olmstead 2007a Evolution of a charismatic Neotropical clade: molecular phylogeny of Tabebuia s. l., Crescentieae, and allied genera (Bignoniaceae). Syst Bot 32:650-659.

$2007 b$ Taxonomic revisions in the polyphyletic genus Tabebuia s. 1. (Bignoniaceae). Syst Bot 32:660-670.

Johri BM, KB Ambegaokar, PS Srivastava 1992 Comparative embryology of angiosperms. Springer, Berlin.

Kapil RN, SC Tiwari 1978 The integumentary tapetum. Bot Rev 44:457-490.

Lau S, D Slane, O Herud, J Kong, G Jurgens 2012 Early embryogenesis in flowering plants: setting up the basic body pattern. Annu Rev Plant Biol 63:483-506.

Leinfellner W 1973 Das Gynözeum der Bignoniaceen. III. Crescentieae (Amphitecna, Colea, Rhodocolea, Ophiocolea, Phyllarthron, Phylloctenium, Parmentiera, Enallagma und Crescentia). Oesterr Bot Z 122:59-73.

Mattos JR 1970 Handroanthus, um novo gênero para os "ipês" do Brasil. Loefgrenia 50:1-4.

Mauritzon J 1935 Etwas über die Embryologie der Bignoniaceen. Bot Notiser 1935:60-77.

McDowell EM, B Trump 1976 Histological fixatives for diagnostic light and electron microscopy. Arch Pathol Lab Med 100:405-414.

Mehra KR, AR Kulkarni 1985 Embryological studies in Bignoniaceae. Phytomorphology 35:239-251.

O’Brien TP, ME McCully 1981 The study of plant structure: principles and selected methods. Termarcarphi Pty, Melbourne.

Olmstead RG, ML Zjhra, LG Lohmann, SO Grose, AJ Eckert 2009 A molecular phylogeny and classification of Bignoniaceae. Am I Bot 96:1731-1743.

Plant List 2013 Plant list. Version 1.1. http://www.theplantlist.org/. Accessed May 9, 2015.

Rembert DH Jr 1972 Phylogenetic significance of megaspore tetrad patterns in Leguminales. Phytomorph 21:1-9.

Renó LR, IS Moscheta, AL Braccini 2007 Morfo-anatomia do fruto e semente de amarelinho (Tecoma stans (L.) Kunth - Bignoniaceae). Rev Bras Sem 29:18-30.

Rodkiewicz B 1970 Callose in cell walls during megasporogenesis in angiosperms. Planta 93:39-47.
Sampaio DS, ME Costa, AAS Paoli 2007 Ontogenia da semente de Tabebuia ochracea (Cham.) Standl. (Bignoniaceae). Rev Bras Bot 30:289-302.

Sampaio DS, NS Bittencourt Jr, PE Oliveira 2013a Mating in the pseudogamic apomictic Anemopaegma acutifolium DC: another case of pseudo-self-compatibility in Bignoniaceae? Plant Biol 15:919-924.

$2013 b$ Sporophytic apomixis in polyploid Anemopaegma species (Bignoniaceae) from Central Brazil. Bot I Linn Soc 173:77-91.

Southworth D 1973 Cytochemical reactivity of pollen walls. IHistochem Cvtochem 21:73-80.

Souza LA, MC Iwazaki, IS Moscheta 2005 Morphology of the pericarp and seed of Tabebuia chrysotricha (Mart. ex DC.) Standl. (Bignoniaceae). Braz Arch Biol Technol 48:407-418.

Souza LA, SO Oyama, JC Muneratto 2008 Morfología y anatomía del fruto en desarrollo de Macfadyena unguis-cati (L.) A. H. Gentry, Bignoniaceae. Acta Bot Venez 31:1-14.

Spangler RE, Olmstead RG 1999 Phylogenetic analysis of Bignoniaceae based on the cpDNA gene sequences of $r b c \mathrm{~L}$ and $n d b \mathrm{~F}$. Ann Mo Bot Gard 86:33-46.

Swamy BGL 1941 Contributions to the life history of Bignonia megapotamica. J Indian Bot Soc 20:299-305.

Tilton VR 1980 Hypostase development in Ornithogalum caudatum (Liliaceae), and notes on the other types of modifications in chalaza of angiosperm ovules. Can I Bot 58:2059-2066.

Tilton VR, NR Lersten 1981 Ovule development in Ornithogalum caudatum (Liliaceae) with a review of selected papers on angiosperm reproduction. III. Nucellus and megagametophyte. New Phvtol 88:477-504.

Tobe H 1989 The embryology of angiosperms: its broad application to the systematic and evolutionary study. Bot Mag Tokvo 102: 351-367.

Ueda M, T Laux 2012 The origin of the plant body axis. Curr Opin Plant Biol 15:578-584.

Williams JH, WE Friedman 2002 Identification of diploid endosperm in an early angiosperm lineage. Nature 415:522-526.

Zhang Z, T Laux 2011 The asymmetric division of the Arabidopsis zygote: from cell polarity to an embryo axis. Sex Plant Reprod 24:161-169. 